\title{
Recorregut de recerca geològica i mineralògica per la comarca del Pallars Jussà: des d'Erinyà a la Pobla de segur, a Tremp i a Isona, tot passant per Figuerola d'Orcau, Basturs i Abella de la Conca
}

Josep Maria Mata-Perelló

Joaquim Sanz Balagué

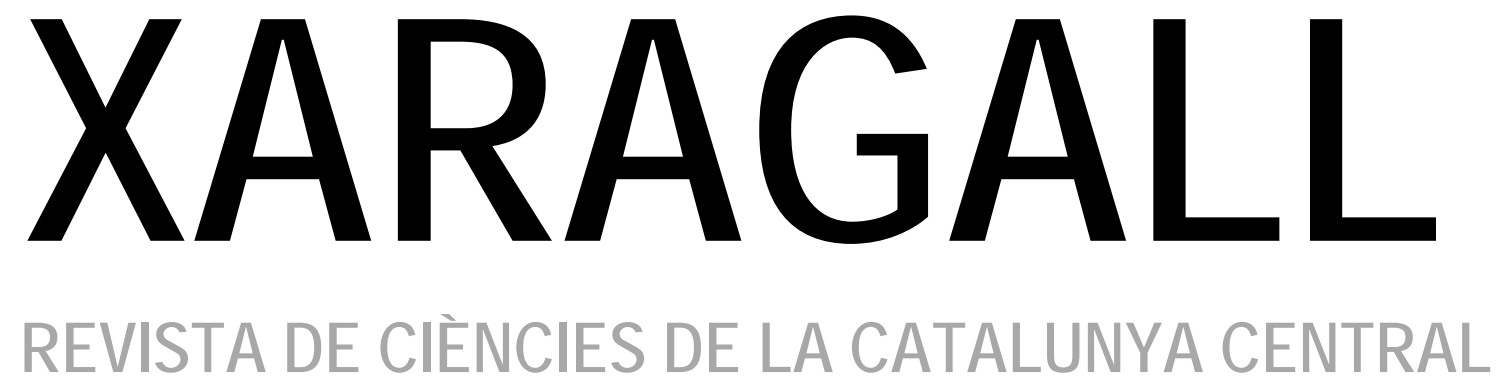

\section{n. 8}

AGOST 2014 


\title{
RECORREGUT DE RECERCA GEOLÒGICA I MINERALÒGICA PER LA COMARCA DEL PALLARS JUSSÀ: DES D'ERINYÀ A LA POBLA DE SEGUR, A TREMP I A ISONA, TOT PASSANT PER FIGUEROLA D'ORCAU, BASTURS I ABELLA DE LA CONCA
}

\author{
Josep Maria Mata-Perelló \\ Museu de geologia Valentí Masachs, Escola Politècnica Superior d'Enginyeria de Manresa \\ (EPSEM), Universitat Politècnica de Catalunya · BarcelonaTech (UPC), 08272 Manresa, Spain
}

\section{Joaquim Sanz Balagué}

Departament d'Enginyeria Minera i Recursos Naturals (EMRN), Escola Politècnica Superior d'Enginyeria de Manresa (EPSEM), Universitat Politècnica de Catalunya . BarcelonaTech (UPC), 08272 Manresa, Spain

Paraules clau: Sistema pirinenc; Patrimoni miner

\section{Resum}

Itinerari realitzat el 8 de setembre de 2013. En aquesta ocasió, el recorregut de l'itinerari discorrerà, en la seva quasi totalitat pel Sistema Pirinenc, i més concretament ho farà per la seva Unitat Sudpirinenca Central (també anomenada com a les Serres Exteriors Prepirinenques).

En concret, el recorregut del present itinerari passarà per dos dels seus sectors més representatius; concretament pel Mantell del Montsec (més situat al Sud) i també per alguns indrets del Mantell de Bóixols.

Així, l'itinerari s'iniciarà dintre del Mantell de Bóixols (molt prop de la Unitat de les Nogueres) però les immediacions de la Pobla de Segur, a Erinyà, per a penetrar-se més endavant al Mantell del Montsec, per on finalitzarà el recorregut de l'itinerari.

Per d'altra banda, el recorregut de l'itinerari discorrerà íntegrament per una sola comarca: per la del Pallars Jussà (de la Regió de Tremp). 


\section{Objectius fonamentals}

Es centraran en els aspectes geològics, geomorfològics i mineralògics que apuntarem a continuació:

1. Estudi de l'estructura materials dels relleus prepirinencs de la Unitat Sud-pirinenca Central, que es tallaran al llarg del recorregut de tot l'itinerari, entre Erinyà, per les immediacions de la Pobla de Segur i d'Isona. Aquests relleus, es distribuiran entre el Mantell de Bóixols i el Mantell de Montsec.

2. Estudi i observació dels materials mesozoics (del Juràssic i sobretot del Cretàcic), i del cenozoic (fonamentalment de l'Eocè i de l'Oligocè), que formen part dels relleus dels mantells acabats d'esmentar al paràgraf anterior. I, tanmateix dels materials oligocènics postorogènics que ocasionalment els cobreixen.

3. Observació de les relacions existents, dintre de la zona per la qual discorre el recorregut de l'itinerari, entre les zones abans esmentades, del Sistema Pirinenc. (concretament entre el Mantell de Bóixols i del Mantell del Montsec).

4. Observació de l'important jaciment fossilífer dels ous de dinosaures, situat prop de Basturs, entre els sediments cretàcics.

5. Reconeixement de diverses mineralitzacions situades al llarg del recorregut del present itinerari, com les següents, d'acord amb el sentit de la marxa, tot i que en general seran poc importants.

6. Observació dels diferents indrets relacionats amb el patrimoni geològic que anirem trobant al llarg del recorregut d'aquest itinerari. En concret, d'acord amb el sentit de la marxa, cal parlar de:

6a) del Congost d'Erinyà, obert pel Noguera de Flamisell, al travessar les calcàries cretàciques del Mantell de Bóixols.

6b) de l'important jaciment fossilífer de Basturs, caracteritzat per la presència d'ous de dinosaures

6c) dels coneguts Estanys de Basturs, molt afectat els darrers anys per l'extracció d'aigües il-legal, per tal de pal-liar la sequera

6d) del congost d'Abella de la Conca, directament relacionat amb l'encavalcament de l'Abella

7. Observació dels diferents indrets relacionats amb el patrimoni miner, si s'escau, que anem trobant al llarg del recorregut d'aquest itinerari. 


\section{Antecedents}

En relació amb aquest itinerari geològico-mineralògic, existeixen diversos antecedents nostres: Mata-Perelló (1995, 1996a, 1996b, 1996c, 1996d, 1999, 2002a, 2002b i 2009); així com de Mata-Perelló i Montané (2002, 2005a, 2005b i 2006). Es tracta, en tots els casos, d'itineraris similars al que ara tractarem, i que discorren per aquestes mateixes comarques en la seva major part del recorregut.

Pel que fa a les mineralitzacions que veurem en aquest itinerari, cal dir que també ja estat prèviament descrites per nosaltres mateixos en Mata-Perelló (1991). En aquest treball es fa referència a les mineralitzacions catalanes en general, parlant-se també de les situades al llarg d'aquest itinerari; i que es distribueixen tant per la Noguera, com pel Pallars Jussà.

I pel que fa a l'estructura geològica, ens remetérem a Riba et altri (1976), i a Guimerà et altri (1992). En ambdós treballs, es fa referència a l'estructura geològica dels Països Catalans. Per d'altra banda, també ens cal fer referència de Rosell (1970); així com de l'IGME (1994).

Finalment, cal dir que tots aquests treballs, es trobaran relacionats, per estricte ordre alfabètic, dintre de l'apartat dedicat a les REFERĖNCIES BIBLIOGRÀFIQUES, al qual es remetem, pel que s'escaigui.

\section{Recorregut de l'itinerari}

Aquest itinerari, s'iniciarà per les immediacions de la Pobla de Segur, concretament al Congost $d^{\prime} E$ Erinyà, per on es farà la primera aturada, prop de la carretera nacional $\mathrm{N}-260$. Tot seguit, des de la Pobla de Segur des continuarà per la carretera que es dirigeix cap a Tremp, la carretera autonòmica C -13 . Després, des d'aquesta darrera població, ens convindrà continuar cap a llevant, seguint ara la carretera C - 1412c. Poc després s'arribarà a Vilamitjana. En aquest recorregut es farà una nova aturada.

Després es continuarà per la carretera local que es dirigeix cap a les petites poblacions de Figuerola d'Orcau i de Conques, la $\mathrm{C}-1412 z$. Des de prop de la primera població s'anirà cap a Basturs. Així es seguirà la carretera local L - 5113. En aquest tram es faran tres noves aturades, dos d'elles prop del darrer poble esmentat.

Posteriorment, el recorregut es dirigirà cap a les immediacions d'Abella de la Conca, des d'on s'anirà finalment cap a Isona, seguint ara la carretera local L - 511. En arribar a aquesta darrera població, finalitzarà el recorregut d'aquest itinerari, després de retornar a la carretera autonòmica C - 1412c. En aquest tram de l'itinerari, es faran dues noves aturades. 


\section{Advertiments previs}

Com en altres recorreguts de RECERCA GEOLÒGICA I MINERALÒGICA... si es disposa del temps suficient, poden efectuar-se passant per totes les parades i filloles. En cas contrari, recomanem prescindir de les anomenades PARADES - CONDICIONALS.

Per d'altra banda, cal tenir cura del coneixement de l'estat de conservació d'alguns dels trams dels camins a recórrer. En concret, del que ens ha de conduir des del poble de Basturs al jaciment d'ous de dinosaures, o als Estanys de Basturs. També és el cas del camí que ens conduirà cap al jaciment de la Posa.

Per d'altra banda, i a l'igual que en altres recorreguts semblants, recomanem tenir el màxim de cura i de respecte, entorn de la Natura que ens rodeja.

\section{Descripció de l'itinerari}

Com ja és habitual, farem una sèrie de PARADES (o de ESTACIONS). En cada una d'elles, farem esment del terme municipal on es troben (en cas que no quedi clar, al situar la parada), així com del número del MAPA TOPOGRÁFICO NACIONAL (a escala 1:50.000), que indicarem entre parèntesi.

Per d'altra banda, en cada una de les parades indicarem el nom del municipi, en el qual es troben situades. També indicarem el nombre de la comarca en el qual es troba situada. En aquesta ocasió, utilitzarem els dos següents fulls: 252 (Tremp) i 253 (o d'Organyà). Tots aquests fulls, han estat publicats per Instituto Geogràfico y Catastral de España.

Així doncs, la relació general ordenada de les aturades que composen aquest itinerari, es el següent:

\subsection{Parada 1. TRENCALL D’ERINYÀ - CONGOST D'ERINYÀ (Erinyà, de l'antic terme de Toralla-Serradell, i a l'actualitat del terme mal anomenat Pallars Jussà, comarca del Pallars Jussà). (Full 252).}

El recorregut de l'itinerari el començarem per les immediacions del poblet d'Erinyà. Concretament, ho farem al trencall cap aquest poble, des de l'actual carretera N-260 (l'antiga carretera comarcal C-144). Des d'aquest trencall anirem cap el proper Congost d'Erinyà. En arribar-hi es farà la primera aturada, a uns $0^{\prime} 5 \mathrm{Km}$ del trencall de la $\mathrm{N}-260$.

Aquest breu recorregut, l'haurem efectuat entre els afloraments del materials cretàcics (del Cretàcic Superior) i dels terrenys de l'Eocè, que formen part de l'extrem septentrional del Mantell del Montsec. Cal dir que molt sovint aquests materials es troben coberts, pels terrenys detrítics postorogènics de l'Oligocè, constituïts per nivells de conglomerats.

Des d'aquest indret, on ara ens trobem situats, es pot gaudir d'un bon lloc d'observació de la discordança entre els nivells calcaris del Cretàcic del Mantell de Bóixols (Unitat Sud-pirinenca Central) i els nivells de conglomerats postorogènics de l'Oligocè. (fotografia 1 ).

També, des d'aquest indret (o fent un curt desplaçament d'uns 200 metres) es pot veure el Congost d'Erinyà. Aquest ha estat obert per la Noguera de Flamisell (o Riu Flamisell), en travessar les roques carbonatades cretàciques, de les que hem fet esment anteriorment. (fotografia 2).

Xaragall.2014 n.8 | Recorregut de recerca geològica i mineralògica per la comarca del Pallars Jussà: des 


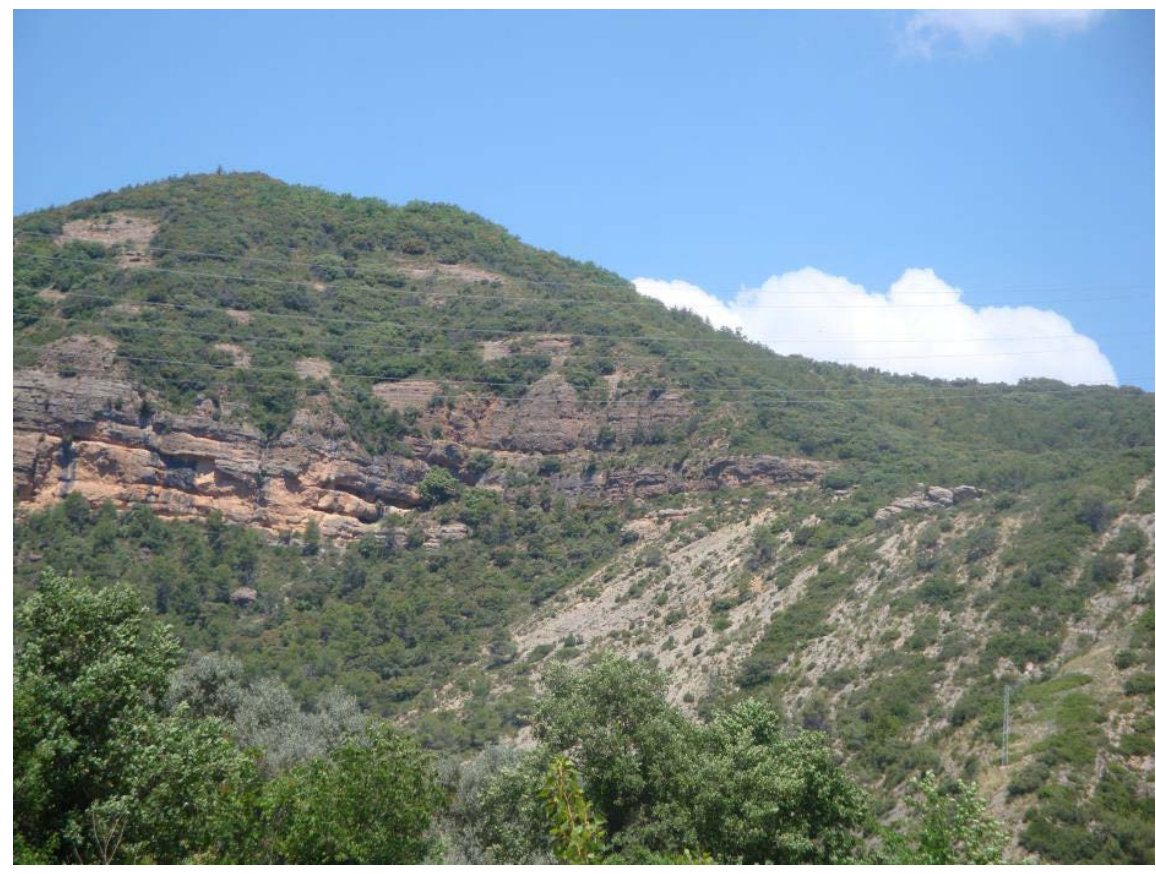

Fotografia 1. Discordança angular del Congost d'Erinyà. A l'esquerra de la fotografia, es poden veure els nivells detrítics de I'Oligocè (rogencs). A la dreta, es poden veure els nivells calcaris cretàcics del Mantell de Bóixols (grisos). Juny del 2009

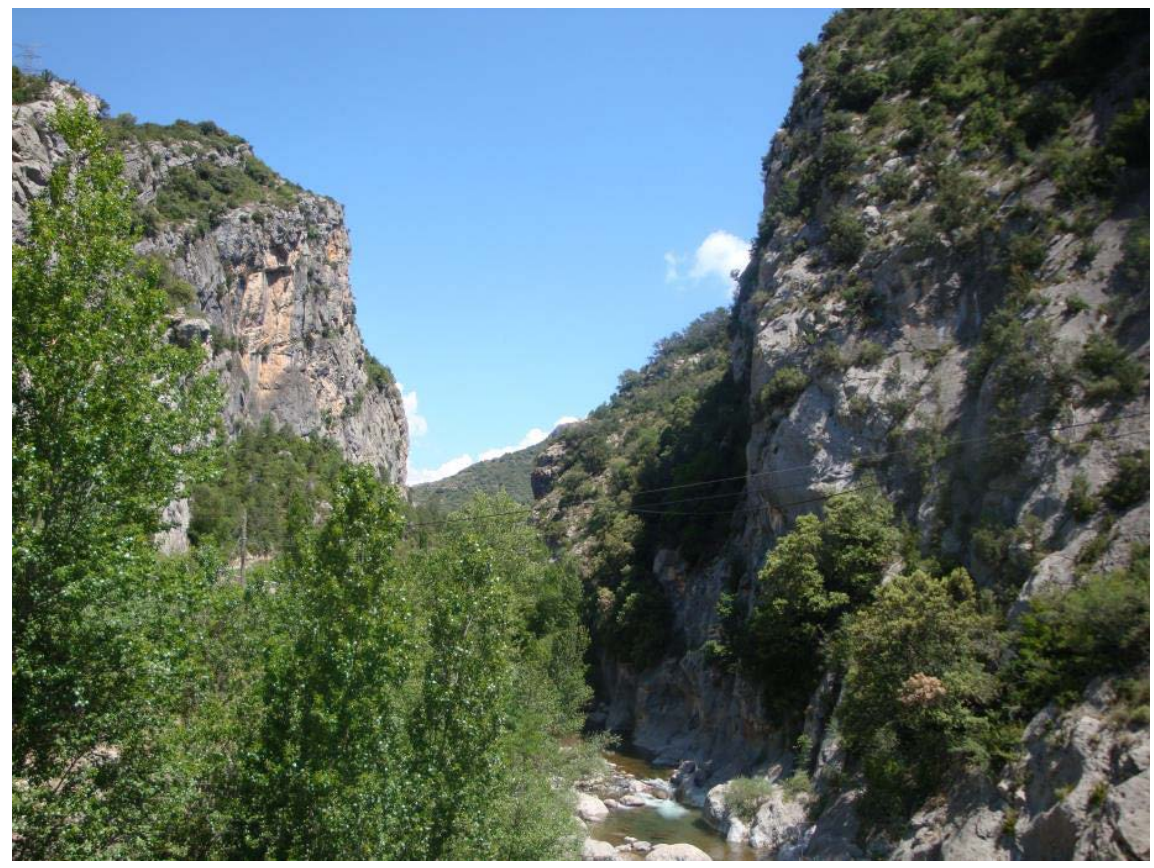

Fotografia 2. El Congost d'Erinyà. Juny del 2009

Xaragall.2014 n.8 | Recorregut de recerca geològica i mineralògica per la comarca del Pallars Jussà: des 


\subsection{Parada 2 - CONDICIONAL. PUJADA CAP AL POBLE DE TALARN, (terme municipal de Talarn, comarca del Pallars Jussà). (Full 252).}

Després de realitzar la parada anterior. Ens caldrà agafar la carretera $N-260$, per tal d'anar cap a la Pobla de Segur. En arribar-hi, just a la rotonda de l'entrada, ens caldrà seguir per la carretera autonòmica $\mathrm{C}-13$, anant ara cap a Tremp. Així, després de passar per les immediacions de Salas de Pallars, aviat arribarem al trencall de Talarn, per on caldrà fer una nova aturada, després de recórrer uns $10 \mathrm{Km}$ des de la Pobla de Segur i uns 15 des del Congost d’Erinyà.

En aquest recorregut haurem trobat els afloraments dels materials mesozoics del Cretàcic, els quals formen part dels afloraments més septentrionals del Mantell del Montsec, on estem ara situats.

En aquest indret es pot fer una bona observació dels materials del Garumnià, de tonalitats rogenques. Aquests materials eminentment continentals en aquest indret, constitueixen el trànsit del Cretàcic al Paleocè.

\subsection{Parada 3. IMMEDIACIONS DEL TRENCALL DE FIGUEROLA D’ORCAU, (Figuerola d'Orcau, terme municipal d'Isona i la Conca Dellà, comarca del Pallars Jussà). (Full 252).}

Després de fer la parada anterior, cal continuar cap a Tremp, seguint la carretera autonòmica C - 13. Després, a la sortida de la darrera població esmentada, ens caldrà continuar per la carretera comarcal C-1412b. Per ella es passarà aviat per Vilamitjana. Posteriorment (després de deixar enrere el trencall de Sant Salvador de Toló així com el nou vial cap a Isona), s'arribarà prop del trencall de Figuerola d'Orcau, d'on surt la carretera C - 1412z. Per aquest indret farem una nova aturada, després de recórrer uns $17 \mathrm{Km}$, des de la parada anterior.

En aquest recorregut, hem anat trobant els materials esmentats a l'aturada anterior, els quals pertanyen als trams finals del Garumnià. Així, arreu veurem afloraments dels terrenys rogencs, constituïts per calcolutites i per gresos, fonamentalment. Aquests són els materials que apareixen a l'indret de la present aturada.

\subsection{Parada 4. JACIMENT D'OUS DE DINOSAURES DE BASTURS, (Basturs, terme municipal d'Isona i la Conca Dellà, comarca del Pallars Jussà). (Full 252).}

Després de fer la parada anterior, cal continuar per la carretera local LV - 5113, per tal d'anar cap al poble de Basturs. Aquí, en arribar a la plaça, cal seguir pel camí de l'esquerra dels dos que parteixen en direcció nord, seguint aquest camí fins que aquest talla el rierol del barranc de la Costa Grau. Aquí cal deixar els cotxes, per tal de continuar caminant fins trobar-nos amb uns materials de color vermell que cabussen fortament vers el sud constituint d'indret anomenat Costa dels Corrals. Aquí es farà una nova aturada, a uns $8 \mathrm{~km}$ de la parada anteriorment realitzada.

En aquest recorregut, hem anat trobant, fonamentalment, els materials que ja hem esmentat a les dues aturades anteriors. Aquests materials cretàcics pertanyen al Garumnià i es troben a l'extrem septentrional del Mantell del Montsec. 
Els materials que aquí trobem són gresos litorals d'edat maastrichtiana molt tardana. Ens crida l'atenció unes partícules allargades de color gris clar / blanc que contrasten amb el vermell de la resta de components d'aquest gres.

Si ens mirem en detall aquestes partícules blanques allargassades apreciarem com un del seus marges és llis mentre que l'altre és granellut i com tota la partícula està solcada, perpendicularment a aquests marges més llargs, per porus. Aquestes partícules no són res mes que fragments de closques d'ous de dinosaure; si resseguim un xic aquest aflorament ens trobarem amb porcions grans de closca, ous més o menys sencers i potser algun niu. Cal notar com la mida i el número de porus apreciables en aquests fragments d'ou són elevats.

Aquest fet ens indica que l'embrió necessitava una bona ventilació per poder desenvolupar-se, d'aquí podem deduir què els ous no es podien pondre ni molt prop de l'aigua ni massa soterrats en l'arena. Apart d'alguna estructura sedimentària pròpia de les platges també podem trobarnos fàcilment amb burrows, unes biotorbacions t'aproxima-les-en $10 \mathrm{~cm}$ de llarg i un diàmetre que oscil.la entre un i dos centímetres que presenten diferents laminacions en forma de menisc còncau vers els fons de l'estructura. Aquestes biotorbacions s'atribueixen a algun tipus de crustaci, possiblement un petit cranc.

De ben segur que la particularitat què més ens crida l'atenció d'aquest jaciment és la gran quantitat d'ous que hi ha i el fet de que tots siguin iguals, possiblement pertanyen a una única espècie encara desconeguda doncs, en cara no s'ha trobat cap os de dinosaure en aquest jaciment ni cap ou amb l'embrió en l'interior.

Amb totes aquestes dades podem fer una interpretació de la història d'aquesta platja de les acaballes del Mesozoic. Tots els ous que hi ha en aquesta platja semblen ser de la mateixa espècie, això i la gran quantitat que n'hi ha ens porta a pensar que es tracta d'un lloc de nidificació, una colònia on uns grans dinosaures acudien per procurar la seva descendència. Aquesta colònia de nidificació estava constituïda per individus sans. Podem fer aquesta afirmació mercès a la absència de restes esquelètiques. De la mateixa manera podem intuir que aquí no hi havia depredació.

Un tipus de cranc es veia beneficiat per l'afluència de dinosaures. La gran quantitat de matèria orgànica aportada a aquesta platja en eclosionar o no els ous de dinosaure possiblement representava un massiu increment temporal de nutrients, aquest era aprofitat per una gran munió d'artròpodes, els autors dels burrows apreciables en el material.

Aquest jaciment de restes de dinosaure, conjuntament amb la resta que tenim en aquesta zona, a Coll de Nargó, Camarasa i altres localitats pirinenques, són un dels tres llocs existents en el planeta on es pot estudiar el trànsit entre el Mesozoic i el Cenozoic. (fotografia 3). 


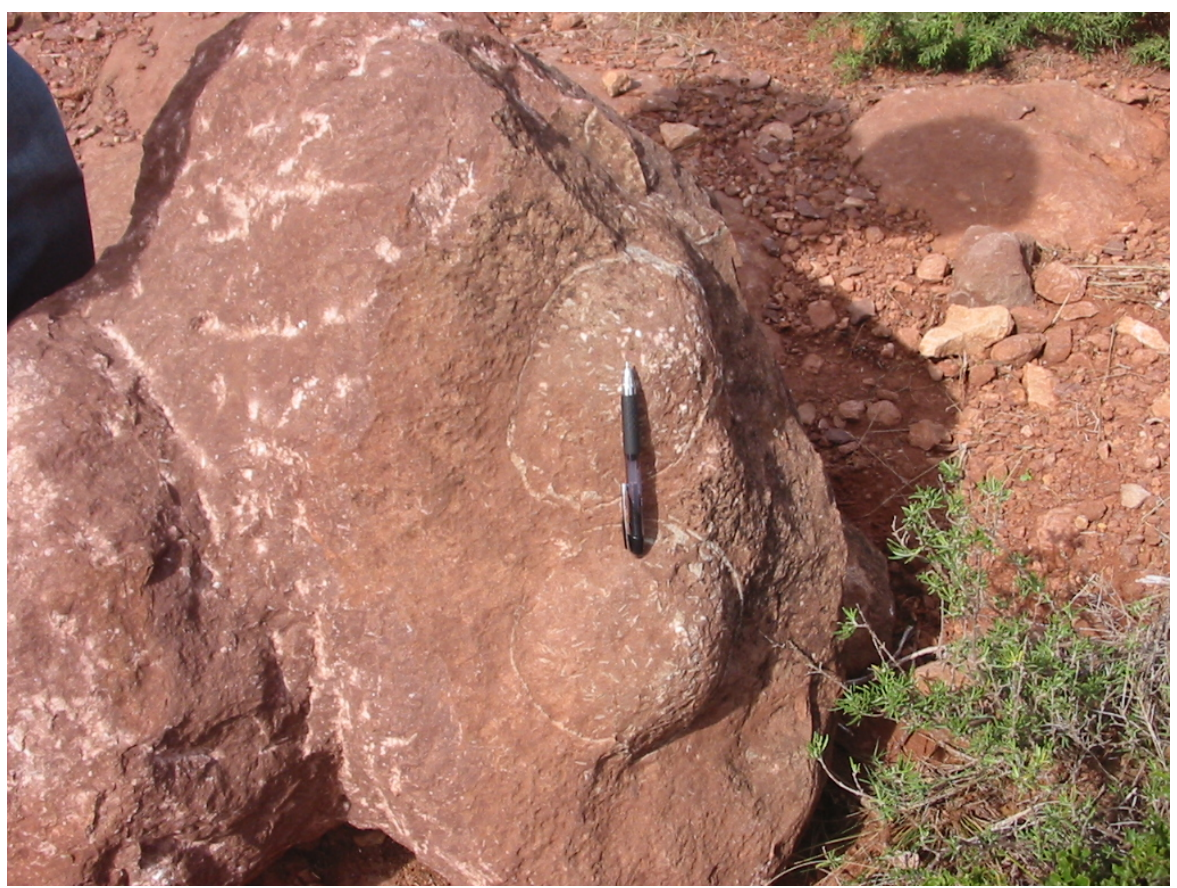

Fotografia 3. Una mostra dels restes dels ous de dinosaure. Febrer 1997

\subsection{Parada 5. ESTANYS DE BASTURS, (Basturs, terme municipal d'Isona i la Conca Dellà, comarca del Pallars Jussà). (Full 252).}

Després de fer l'aturada anterior, ens caldrà retornar cap a Basturs, per tal d'agafar un altre camí que es dirigeix cap a l'indret on hi ha estanys de Basturs, on farem la present aturada, a uns $3 \mathrm{Km}$ de la parada anterior.

En aquest recorregut, hem trobat afloraments dels materials cretàcics, que ja hem esmentat a les aturades anteriors. Com en aquell cas, estem a l'extrem septentrional del Mantell del Montsec

Es tracta de dos llacs kàrstics de característiques similars als també pirinencs t'Estanya (a la comarca de la Ribagorça Oriental) i al de Montcortés (el qual es troba al Pallars Sobirà). La formació d'aquests llacs respon al model de col-lapse d'una cavitat kàrstica, tot formant-se una dolina que resta plena d'aigua per trobar-se en la mateixa cota que el nivell freàtic.

La principal diferència entre aquests llacs i els altres citats és els materials sobre els quals es troben, en aquest cas són calcarenites i calcàries de les fàcies garumnianes que formen part del Sinclinal de Tremp i per tant no situades sobre fronts d'encavalcament (materials triàsics) com és el cas dels esmentats llacs d'Estanya i del llac de Montcortés.

Mereix especial menció la importància dels estanys de Basturs des del punt de vista biològic $\mathrm{i}$ l'alt grau de degradació i contaminació que pateixen per efecte de l'activitat agrícola i ramadera.

Aquests llacs que han estat amenaçats per accions antròpiques (contaminacions, explotació de les seves aigües,...) formen part del nostre Patrimoni Geològic; així com del Patrimoni Natural i cal protegir-los davant de qualsevol acció contra ells i el seu entorn. (fotografia 4). En aquesta fotografia es mostra un dels estanys mig assecat, afortunadament, més endavant s'ha anat recuperant. 


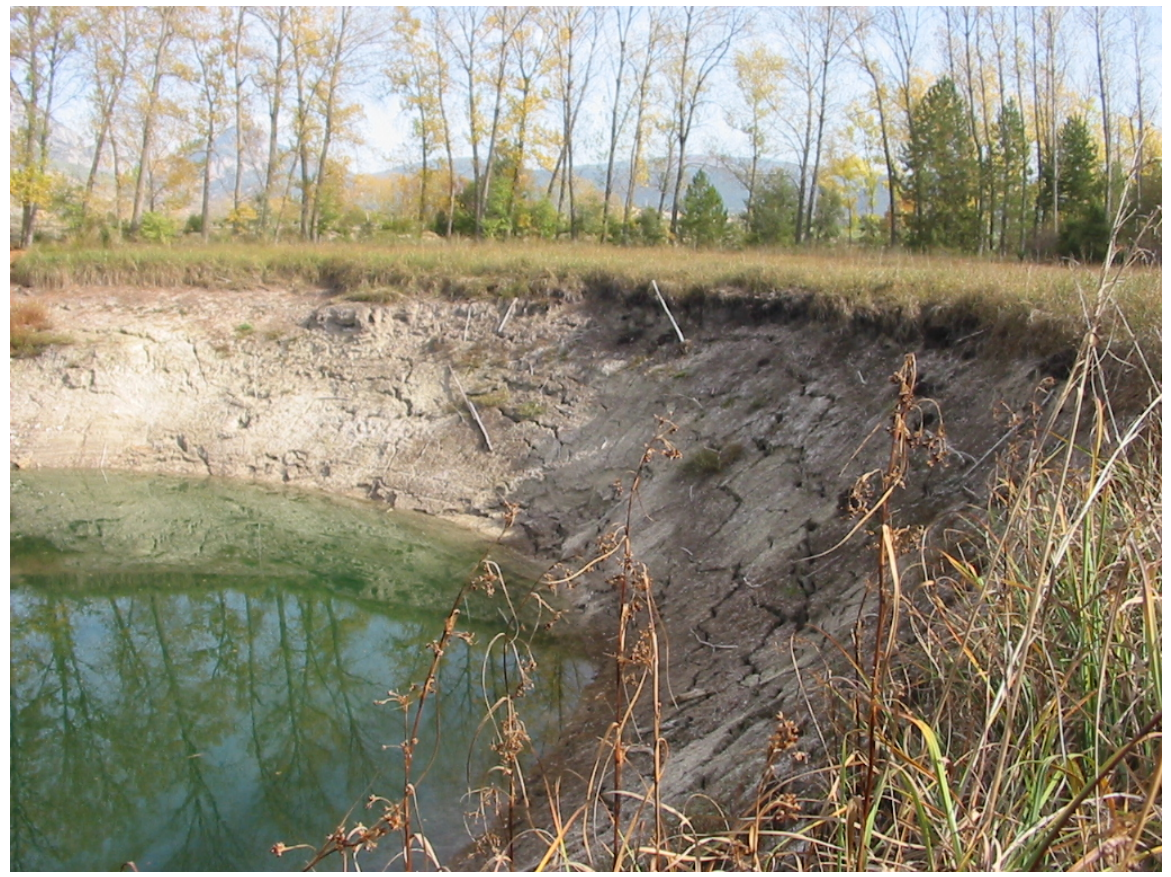

Fotografia 4. Un dels estanys, mig dessecat (tardor del 2005, octubre)

\subsection{Parada 6. ENTRADA AL POBLE D’ABELLA DE LA CONCA, (Abella de la Conca, terme municipal d'Abella de la Conca, comarca del Pallars Jussà). (Full 252).}

Després de fer la parada anterior, cal seguir cap al proper poble de Sant Romà d'Abella. En arribar al poble, tot fent una fillola, ens cal agafar el camí d'Abella de la Conca, per on farem una nova fillola. En arribar-hi farem una nova aturada, després de recórrer uns $8 \mathrm{Km}$ des de la parada anterior.

En aquest recorregut, hem anat tallant els materials esmentats a la parada anterior. Per d'altra banda, des de bona part del recorregut, hem pogut veure des de lluny l'impressionant encavalcament d'Abella, corresponent al Mantell de Bóixols sobre el Mantell del Montsec. Ara, en arribar al poble, el podem veure des de ben a prop.

També, des d'aquí es pot veure el congost que forma el riu Abella en travessar les calcàries cretàciques, que formen part de l'esmentat encavalcament. Així, des d'aquí podem veure el Congost d'Abella de la Conca. Aquest congost, denominat lo Forat d'Abella (i popularment lo Foradot), ha estat obert per aquest riu, en travessar la Serra de Carrànima. De fet, hi ha tres congostos successius, originats pel riu en trobar-se els diferents fronts d'encavalcament del Mantell de Bóixols sobre l'extrem septentrional del Mantell del Montsec.

També podem veure el front d'encavalcament sobre les mateixes cases del poble. Aquest lloc on ara ens trobem és un interessant indret, el qual pot formar part del nostre Patrimoni Geològic. (fotografia 5). 


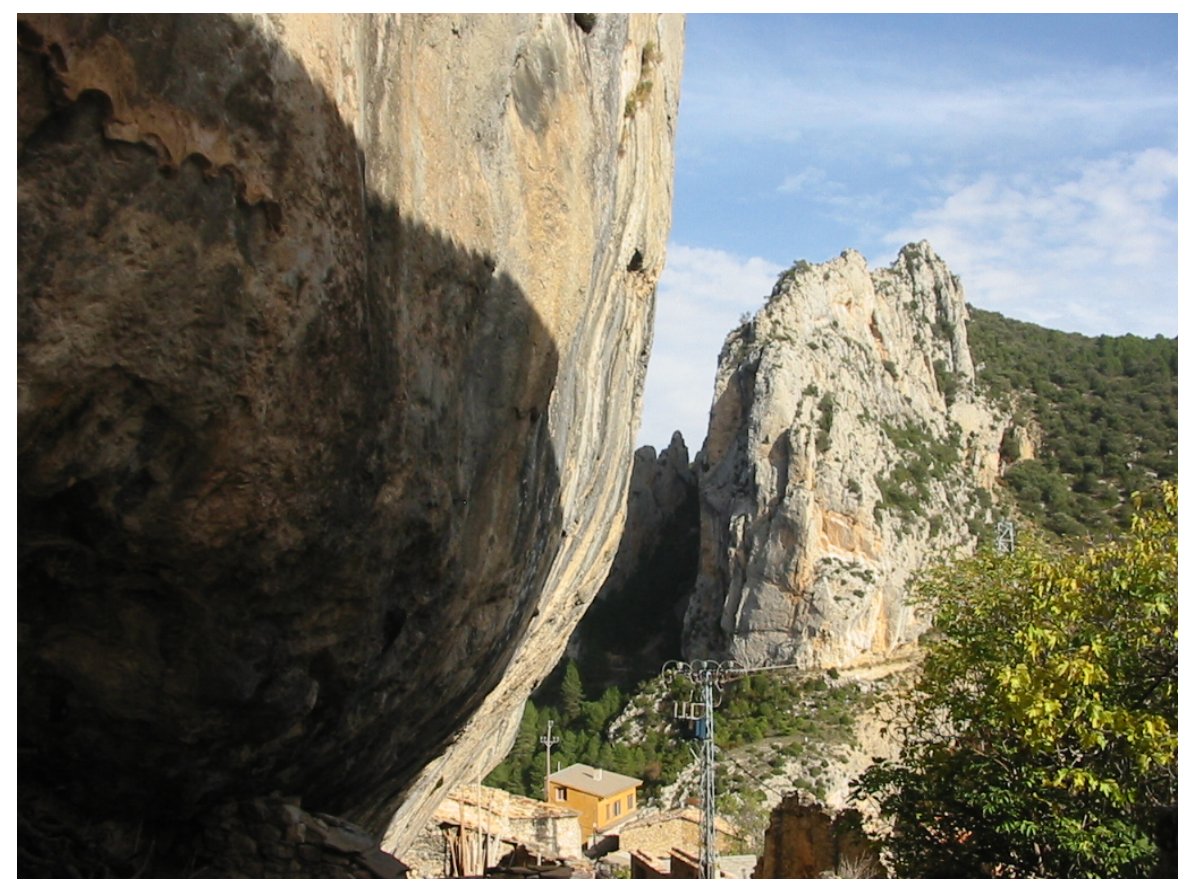

Fotografia 5. Un aspecte del front d'encavalcament del Mantell de Bóixols, amb el poble i el congost d’Abella de la Conca (lo Foradot), obert pel riu Abella.

\subsection{Parada 7 - CONDICIONAL.PARC CRETÀCIC DE LA POSA. (Santuari de la Mare de Deu de la Posa, terme municipal d'Isona i la Conca Dellà, comarca del Pallars Jussà). (Full 252).}

Després de fer la parada anterior, cal sortir d'Abella de la Conca per la carretera, amb la intenció d'arribar a la cruïlla amb la que uneix Isona i Coll de Nargó (la L - 511). En trobar-la, quasi a la mateixa cruïlla hi ha l'inici del camí que condueix cap el Santuari de la Posa, tot i així, a la cruïlla haurem de fer un petit desplaçament cap el Sud. En trobar aquest camí, ens hi caldrà anar. Així, enllà farem la darrera aturada d'aquest itinerari, a uns $4 \mathrm{Km}$ de la darrera aturada, aproximadament. I també a uns $3 \mathrm{Km}$ d'Isona.

En aquest recorregut, haurem anat trobant els materials esmentats a les parades anteriors. Així, ara ens haurem estat desplaçant entre els afloraments dels materials cretàcics, que formen part dels sectors més septentrionals del Mantell del Montsec. Així, haurem vist afloraments eminentment carbonatats i calcolutítics del Cretàcic Superior, fonamentalment del Garumnià, en arribar a l'indret de la present aturada.

En aquest lloc es troba un interessant jaciment d'icnites (de petjades), que inicialment es van atribuir a dinosaures. Posteriorment, s'ha vist que son icnites de rajades. Tot i això, constitueix un altre indret del interessant del nostre Patrimoni Geològic, al marge de les darreres polèmiques sobre la seva autenticitat.

A l'actualitat, en aquest indret s'ha situat el Parc Cretàcic de la Posa. Així, per part del Museu d'Isona, s'ha preparat l'indret per a les visites i es poden observar centenars d'icnites de les esmentades rajades. Aquestes es troben per sota de l'ermita, en una vessant de la Colomera.

Xaragall.2014 n.8 | Recorregut de recerca geològica i mineralògica per la comarca del Pallars Jussà: des d’Erinyà a la Pobla de segur, a Tremp i a Isona, tot passant per Figuerola d'Orcau, Basturs i Abella de la 
Per d'altra banda, en aquest indret es poden veure nivellets de lignits, que temps enllà es van intentar d'explotar. Aquests lignits formen part de la Conca Lignitífera d'Isona. Els lignits es situen sobre els afloraments del Garumnià.

En aquest indret finalitza el recorregut de l'itinerari.

\section{Bibliografia}

GUIMERÀ, J. et altri (1992).- Geologia (II), Història Natural dels Països Catalans, Vol.2, 547 pag. Enciclopèdia Catalana, S.A. Barcelona.

IGME (1970).- Mapa Geológico de España, a escala 1.200.000 (Síntesis de la Cartografia existente). Full i memòria nº 24, Berga. Inst. Geol. Minero de España. Madrid.

IGME (1994).- Mapa Geológico de España a escala 1:50.000 (Plan Magna). Fulla i Memòria ${ }^{\circ}$ 252 (Tremp). Inst. GeoMinero y Tecnol. España. Minist. Indústria. Madrid.

MATA - PERELLÓ, J.M. (1991).- Els Minerals de Catalunya. Arxius de la Secció de Ciències, t. XCIII, 442 pag. Institut d'Estudis Catalans. Barcelona.

MATA-PERELLÓ, J.M. (1995).- Itinerari Geològico-Mineralògic pel Pallars Jussà i pel Pallars Sobirà: des de Puimanyons a Sort. Inèdit, 13 pàgines. Barcelona.

MATA - PERELLÓ, J.M. (1996a).- Itinerari geològico-mineralògic per la comarca de la Noguera. des de Montclar d'Urgell a la Foradada, Inèdit. 12 pag. Manresa.

MATA - PERELLÓ, J.M. (1996b).- Itinerari geològico-mineralògic per la Noguera: des de Bellmunt d'Urgell a Vilanova de la Sal, Inèdit, 13pag. Manresa.

MATA - PERELLÓ, J.M. (1996c).- Itinerari geològico-mineralògic per la Noguera: des Montclar d’Urgell a Santa Maria de Meià, Inèdit, 13pag. Manresa.

MATA-PERELLÓ, J.M. (1996d).- Recerca geològica i mineralògica pels dos Pallars: des del pas de Terradets al Pas de Collegats, per Tremp i per Gerri de la Sal. Inèdit. 12 pàgines. Manresa.

MATA-PERELLÓ, J.M. (1999).- Recerca geològica i mineralògica per les comarques de la Noguera i del Pallars Jussà: des del Pont d'Alentorn a Vilanova de Meià, i des del Pas Nou al congost d’Erinyà. Revista Algeps, nº 87, 10 pag. Manresa.

MATA-PERELLÓ, J.M. (2002a).- Recerca geològica i mineralògica per la comarca del Pallars Jussà: des del Port de Comiols a Llimiana i a Tremp. Revista Xaragall, sèrie $B, n^{\circ}$ 194, 8 pag. Manresa.

MATA-PERELLÓ, J.M. (2002b).- Recerca geològica i mineralògica per les comarques del Pallars Jussà i de I'Alta Ribagorça: des de la Pobla de Segur a Xerallo i al Pont de Suert. Revista Xaragall, sèrie $B, \mathrm{n}^{\circ} 195,12$ pag. Manresa.

MATA-PERELLÓ, J.M. (2009).- Recorregut de recerca geològica i mineralògica per la comarca del Pallars Jussà: des de la Pobla de Segur a Tremp i a Isona, tot passant per Basturs, Suterranya i Abella. Inèdit. 8 pàgines. Manresa.

MATA-PERELLÓ, J.M. i MONTANÉ GARCÍA, P. (2002).- Recorregut de recerca geològica i mineralògica per les comarques del Pallars Jussà i del Pallars Sobirà: des de la Font de les Bagasses a l'Estany de Montcortés, tot passant per Basturs. Inèdit. 12 pag. Manresa. 
MATA-PERELLÓ, J.M. i MONTANÉ GARCÍA, P. (2005a).- Recorregut de recerca geològica i mineralògica per les terres dels dos Pallars: des de la Pobla de Segur i Sossís cap a la Torre de Cabdella i a Gerri de la Sal. Inèdit 8 pag. Manresa.

MATA-PERELLÓ, J.M. i MONTANÉ GARCÍA, P. (2005b).- Recorregut de recerca geològica i mineralògica per la comarca del Pallars Jussà: des de la pobla de Segur a Tremp i a Isona, tot passant per les immediacions de Basturs, de Suterranya i de Bóixols. Inèdit. 8 pag, Manresa.

MATA-PERELLÓ, J.M. i MONTANÉ GARCÍA, P. (2006).- Recorregut de recerca geològica i mineralògica per la comarca del Pallars Jussà: des de la Pobla de Segur i les Mines de Sossís cap a Tremp i a Isona, tot passant per Basturs, Suterranya, Abella i la Posa. Inèdit. 10pag. Manresa.

RIBA, O. et altri (1976).- Geografia Física dels Països Catalans, Edit. Ketres, 254 pàgines. Barcelona.

ROSELL SANUI, J. (1970).- Explicació del Mapa Geològic, a escala 1:50.000, corresponent al full no 252 (Tremp). Mapa Geológico de España. Inst. Geológico y Minero de España. Madrid. 